\title{
Biosurfactant Production and Potential Correlation with Esterase Activity
}

Kamaljeet Kaur Sekhon ${ }^{1 *}$, Sunil Khanna² and Swaranjit Singh Cameotra ${ }^{3}$

${ }^{1}$ Department of Biotechnology and Environmental Sciences, Thapar University, India

${ }^{2}$ NIIT University, Rajasthan, India

${ }^{3}$ Institute of Microbial technology, Chandigarh, India

\begin{abstract}
Biosurfactants (microbial surfactants) are surface active compounds produced extracellularly or as part of the cell membrane by several bacterial and fungal species. They have the unique property of reducing the surface and interfacial tension of liquids. Biosurfactants have applications in the field of agriculture, petroleum, microbial enhanced oil recovery, biomedical sciences, cosmetics, food processing and pharmaceuticals. The global biosurfactants market has grown gradually. Regardless of their greater biodegradability and reduced toxicity, cost competitiveness still remains the major concern for biosurfactant production. However, recombinant or metabolically engineered hyper producing strains combined with optimized cultivation conditions have made it possible for many companies to reap the benefits of 'green' biosurfactant technology. Simultaneously, biosurfactants and bioemulsifiers showing esterase activities and having potential applications are reported to form stable oil-water emulsions with hydrophobic substrates such as hexadecane and polyaromatic hydrocarbons. Biosurfactant production and release of esterases by the microbial cells is shown to be synchronized and symbiotically beneficial in some species. Several bacterial biosurfactant and esterase genes have been identified, cloned and expressed for their enhanced production. This review article emphasizes on the present worldwide scenario of biosurfactant production, correlation between biosurfactant production and esterase activity, recent developments in this line of research and future prospects.
\end{abstract}

Keywords: Biosurfactants; Esterases; Bioremediation; Biosurfactantesterase complex

\section{Introduction}

Biosurfactants are amphiphilic compounds produced by a variety of microorganisms. Biosurfactants have unique properties of lowering the surface and interfacial tensions and Critical Micelle Concentration (CMC) in both aqueous solutions and hydrocarbon mixtures just like chemical surfactants $[1,2]$. The worldwide biosurfactants market was worth USD 1,735.5 million in 2011 and according to the recent market report published by Transparency Market Research it is expected to reach USD 2,210.5 million by the year 2018, corresponding to an average annual growth rate of $3.5 \%$ from 2011 to 2018 . With the increased awareness among consumers for environmentally friendly compounds, a number of surfactant manufacturers in the market have budged into the biosurfactant industry. Today there is an enormous increase in the number of biosurfactant companies around the globe. AGAE technologies Ltd, USA have recently introduced R95, an HPLC/ MS grade rhamnolipid, while USA based Jeneil Biosurfactants is already a key player in this field. Other major manufacturers include Fraunhofer IGB (Germany), Cognis (Germany and USA) dealing with production of glycolipid surfactants, cellobiose lipids and mannosylerythritol lipids; Saraya (Japan), Ecover Belgium (Belgium), Groupe Soliance (France) and MG Intobio (South Korea) are responsible for manufacturing sophorolipids. Cognis recently announced the production of green surfactant alkyl polyglucoside $\mathrm{APG}^{\circledR}$, which is made from vegetable oil or starch, at its site in China while Jeneil Biosurfactants, USA are currently selling ZONIX, a biofungicide made from rhamnolipids and RECO, a biosurfactant used in cleaning and recovering oil from storage tanks. Paradigm Biomedical Inc (USA), on the other hand, is committed to research of pharmaceutical products derived from rhamnolipids.

Biosurfactants are well known and well documented for their role in enhancement of the emulsification of hydrocarbons, potentially solubilizing the hydrocarbon contaminants and increasing their availability for microbial degradation. Surfactants, on the other hand, are the organic compounds and main ingredients found in washing powders, soaps, toothpastes, shampoos and detergents, which are recalcitrant in nature and persist in the environment for longer period of time. While the scientists are keen on replacing chemical surfactants with biosurfactants, the real bottleneck still lies in the high cost of production of biosurfactants. Recombinant, nonpathogenic, highyielding strains are being created with the application of latest genome sequencing technologies. With the use of renewable low-cost carbon sources, the yields are being increased, reducing the costs by scaling up the production.

Biosurfactants, which are selective in nature, act on the surfaces of liquids and at times certain enzymes facilitate them in their action for reducing the surface tensions of liquids and/or improving the solubility of water immiscible substrates. Esterases are among such enzymes, which are shown to be produced in the culture media when the biosurfactants production is at its peak, thus forming a complex with biosurfactants and this interplay between the two greatly helps in the emulsification of the hydrophobic substrates (for example: olive oil). Biosurfactants and esterases thus show some sort of symbiotic relationship which is mutually beneficial to them. Biosurfactants, produced by the recombinant strains, are found to be responsible for the enhanced production and activity of esterases and vice versa [3]. This can further be explained by the fact that biosurfactants are known

*Corresponding author: Kamaljeet Kaur Sekhon, Department of Biotechnology and Environmental Sciences, Thapar University, Patiala - 147001, Punjab, India Tel: +91-9417104058; E-mail: kamalsekhon80@yahoo.com

Received October 27, 2012; Accepted November 19, 2012; Published November 23, 2012

Citation: Sekhon KK, Khanna S, Cameotra SS (2012) Biosurfactant Production and Potential Correlation with Esterase Activity. J Pet Environ Biotechnol 3:133. doi:10.4172/2157-7463.1000133

Copyright: (c) 2012 Sekhon KK, et al. This is an open-access article distributed under the terms of the Creative Commons Attribution License, which permits unrestricted use, distribution, and reproduction in any medium, provided the original author and source are credited. 
Citation: Sekhon KK, Khanna S, Cameotra SS (2012) Biosurfactant Production and Potential Correlation with Esterase Activity. J Pet Environ Biotechnol 3:133. doi:10.4172/2157-7463.1000133

Page 2 of 10

to be poteinaceous in nature $[4,5]$ and it is the protein moiety which is responsible for the emulsifying activity or detergent like property of biosurfactants. Esterases and lipases have similar catalytic sites and treatment with a phospholipid can easily convert an esterase into a lipase [6]. Lipases have penetrated into the detergent market like no other enzyme. Today they are being used and have applications in every modern industry. Esterases with their lipase like properties are also known for their role in degradation of natural materials and industrial pollutants [7].

\begin{tabular}{|c|c|}
\hline Biosurfactant type & Producing Microbial species \\
\hline \multicolumn{2}{|l|}{ Glycolipids } \\
\hline Trehalose mycolates & Rhodococcus erythropolis, Arthrobacter paraffineu, Mycobacterium phlei, Nocardia erythropolis \\
\hline Trehalose esters & Mycobacterium fortium, Micromonospora sp., M. smegmatis, M. paraffinicum, Rhodococcus erythropolis \\
\hline Trehalose mycolates of mono, di, trisaccharide & Corynebacterium diptheriae, Mycobacterium smegmati, Arthrobacter sp. \\
\hline Rhamnolipids & Pseudomonas sp. \\
\hline Sophorolipids & Torulopsis bombicola / apicola, Torulopsis petrophilum, Candida sp. \\
\hline Rubiwettins R1 and RG1 & Serratia rubidaea \\
\hline Diglycosyl digyycerides & Lactobacillus fermenti \\
\hline Schizonellins A and B & Schizonella melanogramma \\
\hline Ustilipids & Ustilago maydis and Geotrichum candidum \\
\hline Amino acid lipids & Bacillus sp. \\
\hline Flocculosin & Pseudomonas flocculosa \\
\hline \multicolumn{2}{|l|}{ Phospholipid and Fatty acids } \\
\hline Phospholipids, Fatty acids & $\begin{array}{l}\text { Candida sp., Corynebacterium sp., Micrococcus sp., Acinetobacter sp, Thiobacillus thiooxidans, Asperigillus sp., Pseu- } \\
\text { domonas sp., Mycococcus sp., Penicillium sp. }\end{array}$ \\
\hline \multicolumn{2}{|l|}{ Lipopeptides and lipoproteins } \\
\hline Gramicidins & Bacillus brevis \\
\hline Peptide lipids & Bacillus licheniformis \\
\hline Polymyxin E1 & Bacillus polymyxa \\
\hline Ornithine-lipid & Pseudomonas rubescens, Thiobacillus thiooxidans \\
\hline Viscosin & Pseudomonas fluorescens \\
\hline Serrawettin & Serratia marcescens \\
\hline Cerilipin & Glucunobacter cerius \\
\hline Lysine-lipid & Agrobacterium tumefaciens \\
\hline Surfactin, subtilysin, subsporin & Bacillus subtilis \\
\hline Lichenysin G & Bacillus licheniformis/M 1307 \\
\hline Ornithine lipid & Pseudomonas sp, Thiobacillus sp, Agrobacterium sp, Gluconobacter sp. \\
\hline Amphomycin & Streptomyces canus \\
\hline Chlamydocin & Diheterospora chlamydosporia \\
\hline Cyclosporin A & Tolypocladium inflatum \\
\hline Enduracidin A & Streptomyces fungicidicus \\
\hline Globomycin & Streptomyces globocacience \\
\hline Bacillomycin L & Bacillus subtilis \\
\hline Iturin A & Bacillus subtilis \\
\hline Putisolvin I and II & Pseudomonas putida \\
\hline Arthrofactin & Arthrobacter \\
\hline Fengycin & Bacillus thuringiensis CMB26 \\
\hline Mycobacillin & Bacillus subtilis \\
\hline \multicolumn{2}{|l|}{ Polymeric surfactants } \\
\hline Lipoheteropolysaccharide (Emulsan) & Acinetobacter calcoaceticus RAG-1, Arethrobacter calcoaceticus \\
\hline Heteropolysaccharide (Biodispersan) & Acinetobacter calcoaceticus $A_{2}$ \\
\hline Polysaccharide protein & Acinetobacter calcoaceticus strains \\
\hline Manno-protein & Saccharomyces cerevisiae \\
\hline Carbohydrate-protein & Candida petrophillum, Endomycopsis lipolytica \\
\hline Mannan-lipid complex & Candida tropicalis \\
\hline Mannose/ erythrose lipid & Shizonella melanogramma, Ustiloga maydis \\
\hline Carbohydrate-protein-lipid complex & Pseudomonas fluorescences, Debaryomyces polymorphus \\
\hline Liposan & Candida lipolytica \\
\hline Alasan & Acinetobacter calcoaceticus \\
\hline Protein PA & Pseudomonas aeruginosa \\
\hline \multicolumn{2}{|l|}{ Particulate biosurfactants } \\
\hline Membrane vesicles & Acinetobacter sp. H01-N \\
\hline Fimbriae, whole cells & Acinetobacter calcoaceticus \\
\hline
\end{tabular}

Table 1: Major types of biosurfactants produced by microorganisms. 
The present review will focus on the recent advances in the field of biosurfactant production. Emphasis will also be laid on the correlation between biosurfactants and esterases. The recombinant strains which show enhanced production of biosurfactants as well as esterases can be harnessed in industrial operations for bulk production. This area of research has very scarce literature available and therefore has many promising research prospects and unexplored edges.

\section{Biosurfactants and their Classification}

Biosurfactants have many applications in the field of bioremediation. The term 'biosurfactant' refers to any compound from microorganisms, which has some influence on interfaces i.e. surface active agents, which brings down the interfacial tension between the two liquids. The minimum surface tension value reached and the critical micelle concentration (CMC) needed are the parameters used to measure the efficiency of a surfactant [8]. A successful biosurfactant can reduce the surface tension of water or growth medium from 72 $\mathrm{mN} / \mathrm{m}$ to around $27 \mathrm{mN} / \mathrm{m}$ [9]. Biological surfactants have many advantages over their chemical similitude's as they are easily degraded by the microorganisms, they have low toxicity, they can be produced from very cheap raw materials, they are not easily affected by environmental factors such as temperature, $\mathrm{pH}$, ionic strength and they have the unique property of biocompatibility and digestibility.

Biosurfactants are amphipathic molecules with both hydrophilic and hydrophobic moieties present within the same molecule. The hydrophobic moiety of a biosurfactant is either a long-chain fatty acid, hydroxy fatty acid or $\alpha$-alkyl $\beta$-hydroxy fatty acid and the hydrophilic moiety can be a carbohydrate, amino acid, cyclic peptide, phosphate, carboxylic acid, or an alcohol. While, synthetic surfactants are usually classified according to the nature of their polar groups, microbial biosurfactants are generally classified mainly on the basis of their biochemical composition and microbial origin. The microbial surfactants are complex molecules in the range of peptides, fatty acids, glycolipids, rhamnolipids, lipopeptides and sophorolipids. The low molecular weight biosurfactants are glycolipids whereas the high molecular weight microbial surfactants are generally polyanionic heteropolysaccharides containing both polysaccharides and proteins. The detailed classification of microbial biosurfactants is presented in table 1 .

\section{Improvement in Biosurfactant Production and their Applications}

Biosurfactants are produced by a variety of microbes, secreted either extracellularly or attached to parts of cells, predominantly during growth on water-immiscible substrates. The production of biosurfactants by microorganisms can be during exponential growth or it may be during the stationary phase of growth when the nutrient limiting conditions start prevailing in the growth medium. In case of growth associated biosurfactant production, there exists a parallel relationship between substrate utilization, growth and biosurfactant production. Production of biosurfactants by some microorganisms might be attributable to the presence of certain genes that are turned on in the presence of particular hydrocarbons. These microorganisms are distributed among a wide variety of genera. The hydrocarbon utilizing and biosurfactant producing microbes are mainly from the genera Bacillus, Nocardia, Pseudomonas, Acinetobacter, Flavobacterium, Arthrobacter, Rhodococcus, Mycobacterium, Corynebacterium and Candida.

Studies were undertaken in order to determine how common culturable surfactant producing bacteria are in undisturbed and contaminated sites [10]. Out of 1305 colonies screened for biosurfactant production in mineral salts medium containing $2 \%$ glucose, from the contaminated and undisturbed soils, 45 isolates were positive for biosurfactant production. These 45 isolates were grouped using repetitive extragenic palindromic (REP)-PCR analysis, which yielded 16 unique isolates. $16 \mathrm{~S}$ rRNA gene sequence of each isolate, revealed one new biosurfactant producing microbe, a Flavobacterium sp. Therefore, it was concluded that the biosurfactant producing microbes are present in most soils and can be isolated even by using a relatively limited screening assay.

Extensive studies in order to examine whether biosurfactant production is growth associated were conducted and it was concluded that in Acinetobacter calcoaceticus RAG-1, emulsan or emulsan-like precursors accumulate as capsular material during the exponential growth phase but are released into the medium when the rate of protein synthesis declines i.e. during the stationary phase of growth [11-14]. Similarly, the production of emulsan in A. calcoaceticus and the fermentative production of surface-active agents from Bacillus cereus IAF-346 and Bacillus sp. IAF-343 [15] were found to be growth associated. The production of surfactin in culture broth of Bacillus subtilis [16], rhamnolipids by Pseudomonas aeruginosa [17], exopolysaccharides in A. calcoaceticus $\mathrm{BD} 4$ [18] and rhamnolipid AP-6 in P. fluorescens 378 [19] were all found to be growth associated. In Bacillus subtilis SK320, the production of biosurfactant was also found to be growth associated [3]. Maximum biosurfactant activity was associated with cells at the stationary phase of growth when the nutrient limiting conditions started establishing in the culture medium.

In view of the wide range of industrial applications of biosurfactants as given in table 2 , the current biosurfactant industry is targeting the key parameters affecting the production of microbial surfactants in terms of higher yields and lower production costs. The main approach to achieve the target are through screening of the appropriate microorganism, the use of cheap or waste substrates to reduce the cost of production, media optimization and cost-effective downstream processes to maximize recovery of the end product. Surfactin, produced by Bacillus subtilis, is a cyclic lipopeptide characterized by a $\beta$-hydroxycarbonic acid moiety with strong surface activity as well as antibiotic properties. Production of lipopeptide antibiotic surfactin was carried out using a recombinant Bacillus subtilis [20]. Surfactin yield by the recombinant strain was about $1 \frac{1}{2}$ times as much as that of Bacillus subtilis RB14, the strain in which the surfactin gene originated. Out of the 13 strains of Bacillus subtilis tested for the coproduction of the lipopeptide surfactin and the antifungal lipopeptides of the iturin family, only one produced both lipopeptides with a high yield on synthetic medium [21]. Several L-amino acids and various carbon sources were good substrates for this lipopeptide production. The maximum yield of surfactin was about 110 $\mathrm{mg} / \mathrm{L}$ and that of iturin A about $39 \mathrm{mg} / \mathrm{L} / \mathrm{absorbance}$ unit for the best strain, Bacillus subtilis S 499.

Various cheap substrates such as vegetable oils and oil wastes, plant-derived oils, lactic whey and distillery wastes, starchy substrates, olive oil mill effluent, animal fat, soap stock and molasses have the potential for enhancing biosurfactant production [22]. Glucose has been the carbon source of choice of various researchers [2326]. However, Candida bombicola, one of the few yeast's to produce biosurfactants can produce sophorolipids from both vegetable oils and sugars [27]. Highly insoluble carbon source such as n-hexadecane, paraffinic oil, glycerol, babassu oil for $P$. aeruginosa PA1 [28], soybean curd residue (okara) for B. subtilis YB8 and B. subtilis MI113 [29,30], 
Citation: Sekhon KK, Khanna S, Cameotra SS (2012) Biosurfactant Production and Potential Correlation with Esterase Activity. J Pet Environ Biotechnol 3:133. doi:10.4172/2157-7463.1000133

Page 4 of 10

\begin{tabular}{|c|c|}
\hline Applications & Role of biosurfactants \\
\hline $\begin{array}{l}\text { Environmental } \\
\text { Soil remediation and flushing } \\
\text { Bioremediation }\end{array}$ & $\begin{array}{l}\text { Emulsification through adherence to hydrocarbons, dispersion, foaming agent, detergent, soil flushing. } \\
\text { Emulsification of hydrocarbons, lowering of interfacial tension, metal sequestration. }\end{array}$ \\
\hline $\begin{array}{l}\text { Agriculture } \\
\text { Biocontrol } \\
\text { Phosphate fertilizers } \\
\text { Spray application }\end{array}$ & $\begin{array}{l}\text { Facilitation of biocontrol mechanisms of microbes such as parasitism, antibiosis, competition, induced systemic resistance and } \\
\text { hypo-virulence. } \\
\text { Prevent caking during storage } \\
\text { Wetting, dispersing, suspending of powered pesticides and emulsification of pesticide solutions, promote wetting, spreading and } \\
\text { penetration of toxicant }\end{array}$ \\
\hline $\begin{array}{l}\text { Petroleum production /products } \\
\text { Enhanced oil recovery } \\
\text { De-emulsification } \\
\text { Drilling fluids }\end{array}$ & $\begin{array}{l}\text { Improving oil drainage into well bore, stimulating release of oil entrapped by capillaries, wetting of solid surfaces, lowering of } \\
\text { interfacial tension, dissolving of oil. } \\
\text { De-emulsification of oil emulsions, oil solubilization viscosity reduction, wetting agent. } \\
\text { Emulsify oil, disperse solids, and modify rheological properties of drilling fluids for oil and gas wells. }\end{array}$ \\
\hline $\begin{array}{l}\text { Biological } \\
\text { Microbiological } \\
\text { Pharmaceuticals and therapeutics }\end{array}$ & $\begin{array}{l}\text { Physiological behavior such as cell mobility, cell communication, nutrient accession, cell-cell competition, plant and animal patho- } \\
\text { genesis. } \\
\text { Antibacterial, antifungal, antiviral agents, adhesive agents, immuno modulatory molecules, vaccines, gene therapy }\end{array}$ \\
\hline $\begin{array}{l}\text { Cosmetic } \\
\text { Health and beauty products }\end{array}$ & Emulsifiers, foaming agents, solubilizers, wetting agents, cleansers, antimicrobial agents, mediators of enzyme action. \\
\hline $\begin{array}{l}\text { Food and beverages } \\
\text { Emulsification and } \\
\text { de-emulsification } \\
\text { Functional ingredient } \\
\text { Food processing plants } \\
\text { Fruits and vegetables } \\
\text { Bakery and ice cream } \\
\text { Crystallization of sugar }\end{array}$ & $\begin{array}{l}\text { Emulsifier, solubilizer, demulsifier, suspension, wetting, foaming, defoaming, thickener, lubricating agent. } \\
\text { Interaction with lipids, proteins and carbohydrates, protecting agent. } \\
\text { For cleaning sanitizing } \\
\text { Improve removal of pesticides and in wax coating } \\
\text { Solubilize flavor oils, control consistency, retard staling } \\
\text { Improve washing, reduce processing time } \\
\text { Prevent spattering due to super heat and water }\end{array}$ \\
\hline $\begin{array}{l}\text { Elastomers / plastics } \\
\text { Emulsion polymerization } \\
\text { Foamed polymers } \\
\text { Latex adhesive } \\
\text { Plastic articles } \\
\text { Plastic coating/laminating }\end{array}$ & $\begin{array}{l}\text { Solubilization, emulsification of monomers } \\
\text { Introduction of air, control of cell size } \\
\text { Promote wetting, improve bond strength } \\
\text { Antistatic agents } \\
\text { Wetting agents }\end{array}$ \\
\hline $\begin{array}{l}\text { Industrial cleaning } \\
\text { Janitorial supplies } \\
\text { De-scaling } \\
\text { Soft goods }\end{array}$ & $\begin{array}{l}\text { Detergents and sanitizers } \\
\text { Wetting agents and corrosion inhibitors in acid cleaning of boiler tubes and heat exchangers } \\
\text { Detergents for laundry and dry cleaning }\end{array}$ \\
\hline $\begin{array}{l}\text { Leather } \\
\text { Skins } \\
\text { Tanning } \\
\text { Hides } \\
\text { Dyeing }\end{array}$ & $\begin{array}{l}\text { Detergent and emulsifier in degreasing } \\
\text { Promote wetting and penetration } \\
\text { Emulsifiers in fat liquoring } \\
\text { Promote wetting and penetration }\end{array}$ \\
\hline
\end{tabular}

Table 2: Some major applications of biosurfactants

peat hydrolysate for B. subtilis [31], soybean oil, safflower oil, glycerol for $P$. aeruginosa GS9-119 and DS10-129 [32] and sludge palm oil for Klebsiella pneumoniae WMF02 [33] have been reported to induce high biosurfactant production. Olive oil was an unconventional carbon source used for the production of lipopeptide biosurfactant by Bacillus subtilis SK320 [3] and biosurfactant produced by marine Nocardiopsis B4 [34]. The important finding was the temperature stability of both the biosurfactants increasing their scope of application at higher temperatures like in microbial enhanced oil recovery. Use of numerous inexpensive raw materials for the production of biosurfactants by various microbial species has been summed up in table 3 .

Historical record is rich with data where researchers have worked with the culture parameters and used cheap substrates in order to achieve maximum yield of biosurfactants. Total production yield of the lipopeptides from Bacillus subtilis BBK-1 was about $480 \mathrm{mg} / \mathrm{L}$ at $30^{\circ} \mathrm{C}$ for $24 \mathrm{~h}$ [35], whereas Bacillus sp. strain IAF 343 gave the yield of $1 \mathrm{~g} / \mathrm{L}$ on medium containing only water soluble substrates [15]. P. aeruginosa DS10-129 produced 4.31, 2.98 and $1.77 \mathrm{~g} / \mathrm{L}$ rhamnolipid biosurfactant using soybean oil, safflower oil and glycerol, respectively, as substrates [32]. Bacillus cereus IAF 346 produced a monoglyceride biosurfactant that lowered the surface tension of water to $28 \mathrm{mN} / \mathrm{m}$ with a yield of $1.6 \mathrm{~g} / \mathrm{L}(\mathrm{pH} 6.5)$ and $1.7 \mathrm{~g} / \mathrm{L}(\mathrm{pH} 7.0)$ [15]. B. subtilis grown on medium containing $4 \%$ glucose gave the yield of $1-2 \mathrm{~g} / \mathrm{L}$ of biosurfactant with minimum surface tension of $27 \mathrm{mN} / \mathrm{m}$ [23]. B. licheniformis JF-2 anaerobically produced biosurfactants when grown in glucose rich medium and reduced surface tension of water to $28 \mathrm{mN} / \mathrm{m}$ [25]. Purified lichenysin A from B. licheniformis BAS50 decreased the surface tension of water to $28 \mathrm{mN} / \mathrm{m}$ with a yield of $70-160 \mathrm{mg} / \mathrm{L}$ [26]. The maximum yield of surfactin was about $110 \mathrm{mg} / \mathrm{L}$ by the strain $B$. subtilis $S 499$ [21]. In a recent study the biosurfactant yields obtained from the recombinant strains BioS a, BioS b and BioS c were 2.13, 2.20 and $2.45 \mathrm{~g} / \mathrm{L}$, respectively, which was much higher than obtained from parent Bacillus subtilis SK320 i.e. $1.2 \mathrm{~g} / \mathrm{L}$. The total yield reported as $\mathrm{g} / \mathrm{L}$ was calculated after purifying the biosurfactant using acetone and weighing the lyophilized powder (Figure 1). The recombinant strains not only showed enhanced biosurfactant production, but an increase in the esterase activity as well as surface tension values (Table 4) [3]. Similarly, Bacillus clausii 5B when grown on minimal medium containing $1 \%(\mathrm{w} / \mathrm{v})$ glucose as carbon source gave the total yield of 2.11 g/L after 96 h [36], whereas Kocuria turfanesis BS-J and Pseudomonas 


\begin{tabular}{|c|c|c|}
\hline $\begin{array}{l}\text { Low cost or waste raw } \\
\text { material }\end{array}$ & Biosurfactant type & Producer microbial strain \\
\hline $\begin{array}{l}\text { Soybean oil refinery } \\
\text { wastes }\end{array}$ & Rhamnolipids & $\begin{array}{l}\text { Pseudomonas aeruginosa } \\
\text { AT10 }\end{array}$ \\
\hline $\begin{array}{l}\text { Curd whey and distillery } \\
\text { wastes }\end{array}$ & Rhamnolipid & Pseudomonas aeruginosa BS2 \\
\hline Turkish corn oil & Sophorolipids & $\begin{array}{l}\text { Candida bombicola ATCC } \\
22214\end{array}$ \\
\hline $\begin{array}{l}\text { Sunflower and soybean } \\
\text { oil }\end{array}$ & Rhamnolipid & $\begin{array}{l}\text { Pseudomonas aeruginosa } \\
\text { DS10-129 }\end{array}$ \\
\hline Sunflower oil & Lipopeptide & Serratia marcescens \\
\hline Soybean oil & $\begin{array}{l}\text { Mannosyl erythritol } \\
\text { lipid }\end{array}$ & Candida sp. SY16 \\
\hline $\begin{array}{l}\text { Waste frying oils } \\
\text { (sunflower and olive oil) }\end{array}$ & Rhamnolipid & $\begin{array}{l}\text { Pseudomonas aeruginosa } 47 \mathrm{~T} 2 \\
\text { NCIB } 40044\end{array}$ \\
\hline $\begin{array}{l}\text { Soybean soap stock } \\
\text { waste }\end{array}$ & Rhamnolipid & Pseudomonas aeruginosa LBI \\
\hline $\begin{array}{l}\text { Sunflower oil soap stock } \\
\text { waste }\end{array}$ & Rhamnolipid & Pseudomonas aeruginosa LBI \\
\hline Oil refinery wastes & Glycolipids & $\begin{array}{l}\text { Candida ntarctica and/or } \\
\text { Candida apicola }\end{array}$ \\
\hline Rapeseed oil & Rhamnolipids & Pseudomonas sp. DSM 2874 \\
\hline Babassu oil & Sophorolipids & Candida lipolytica IA 1055 \\
\hline Potato process effluents & Lipopeptide & Bacillus subtilis \\
\hline Cassava flour wastewater & Lipopeptide & $\begin{array}{l}\text { Bacillus subtilis ATCC } 21332 \\
\text { and Bacillus subtilis LB5a }\end{array}$ \\
\hline Olive oil & Lipopeptide & Bacillus subtilis SK320 \\
\hline Sludge Palm oil & Phospholipid & Klebsiella pneumoniae WMF02 \\
\hline
\end{tabular}

Table 3: Use of low cost carbon sources for the production of biosurfactants by various microbial species.

\begin{tabular}{|l|l|l|l|l|l|}
\hline Source & $\begin{array}{l}\text { Biosurfactant } \\
\text { activity } \\
\text { (OD 550 nm) }\end{array}$ & $\begin{array}{l}\text { Esterase } \\
\text { activity } \\
\text { (IU ml-1) }\end{array}$ & $\begin{array}{l}\text { Growth } \\
\text { (OD 600nm) }\end{array}$ & $\begin{array}{l}\text { Biosurfactant } \\
\text { recovery (g/L) }\end{array}$ & $\begin{array}{l}\text { Surface } \\
\text { tension } \\
\text { (dynes/ } \\
\text { cm) }\end{array}$ \\
\hline $\begin{array}{l}\text { Bacillus subtilis } \\
\text { SK320 }\end{array}$ & 0.859 & 4.382 & 0.514 & 1.2 & 40.1 \\
\hline BioS a & 1.354 & 8.293 & 0.351 & 2.13 & 38.4 \\
\hline BioS b & 1.259 & 8.521 & 0.296 & 2.20 & 35 \\
\hline BioS c & 1.198 & 8.465 & 0.489 & 2.45 & 30.7 \\
\hline E. coli DH5a & 0.157 & 0.101 & 0.132 & 0.054 & 11.2 \\
\hline
\end{tabular}

$\dagger$ Results represented as mean of at least three replicate experiments (Sekhon et al, 2011)

Table 4: Bacillus subtilis SK320 and its recombinants showing enhanced activities after successful cloning of the biosurfactant genes.

aeruginosa BS-P when grown on combined distillery waste with other industrial wastes showed the biosurfactant production of $0.967 \mathrm{~g} / \mathrm{L}$ and $1.976 \mathrm{~g} / \mathrm{L}$, respectively [37]. Research conducted on Lactobacillus delbrueckii cultured with peanut oil cake as the sole energy source gave the total biosurfactant yield of $5.35 \mathrm{mg} / \mathrm{ml}$ [38] whereas growth of Corynebacterium kutscheri [39] and Pseudomonas aeruginosa [40] on waste motor lubricant oil and peanut oil cake as carbon source showed the lipopeptide production of $6.4 \mathrm{mg} / \mathrm{ml}$ and $8.6 \mathrm{mg} / \mathrm{ml}$, respectively.

In many other recent studies the total biosurfactant yield has been improved by more innovative methods. Biosurfactant production by Bacillus subtilis SPB1 was effectively improved by response surface methodology, giving the total concentration of $2.93( \pm 0.32) \mathrm{g} / \mathrm{L}$ when 15 $\mathrm{g} / \mathrm{L}$ glucose, $6 \mathrm{~g} / \mathrm{L}$ urea and $1 \mathrm{~g} / \mathrm{L} \mathrm{K}_{2} \mathrm{HPO}_{4}$ was added in the media [41]. In yet another interesting study conducted on Bacilus subtilis SPB1, it was reported that inoculum age and density can drastically influence the yield and total cost of the fermentation process. After optimizing the inocula conditions, the yield of the lipopeptide produced by Bacilus subtilis SPB1 was enhanced to $3.4 \mathrm{~g} / \mathrm{L}$ [42]. Pseudomonas aeruginosa
RS29 produced a rhamnolipid after $48 \mathrm{~h}$ of incubation at $370 \mathrm{C}$ and $\mathrm{pH}$ 7-8 and the yield obtained after optimizing the various environmental factors was $0.80 \mathrm{~g} / \mathrm{L}$ [43].

Since the arrival of biosurfactants, the cost of production and selection of the appropriate cheap material are the main criteria and concern for manufacturers. But with the recent advancements in this field and global awareness among consumers for the bio-based products, it appears inevitable that in the coming few years the high quality microbially produced biosurfactants will completely replace the chemical emulsifiers in many industrial applications.

\section{Correlation Between Biosurfactant Production and Esterase Activity}

Acknowledging the advantages and applications of biosurfactantesterase complex, the correlation in their production during the growth of microbes seemed to have caught attention of many researchers [3,14,44-48]. Studies undertaken on biosurfactant-esterase complex are given in chronological order in table 5 .

More than two decades ago the first report on bioemulsifieresterase complex showing effective emulsification of hydrophobic substrates appeared. Since then many researchers have tried to exploit this unique correlation. An esterase activity was observed both in the cell-free growth medium and on the cell surface of petroleumdegrading bacterium Acinetobacter calcoaceticus RAG-1 (ATCC 31012) [48]. It was shown that the enzyme released from the cell surface was either emulsan free or associated with the bioemulsifier. Because of this reason the role for cell bound esterase in the release of emulsan (mol. wt. 106) from the surface of A. calcoaceticus was proposed and in turn suggested that the release process of emulsan involves the cleavage of the ester bond involved in the association of emulsan with the cell surface. The extracellular polyanionic, heteropolysaccharide bioemulsifier emulsan produced by oil-degrading microorganism A. venetianus RAG-1 formed and stabilized oil-water emulsions with a variety of hydrophobic substrates. Removal of the protein fraction yielded a product, apoemulsan, which exhibited much lower emulsifying activity on hydrophobic substrates such as n-hexadecane. Part of this activity could be recovered by the addition of larger amounts of the crude denatured protein [49]. Purified deproteinized emulsan (apoemulsan, $103 \mathrm{kDa}$ ) consisted of $\mathrm{D}$-galactosamine, L-galactosamine uronic acid (pKa, 3.05), and a diamino, 2-deoxy n-acetylglucosamine [50]. The key protein associated with the emulsan complex was later found to be a cell surface esterase [14]. The amphipathic properties of this biopolymer were due in part to the presence of $15 \%$ fatty acids covalently bound to the polysaccharide backbone in both ester and amide linkages [51]. When recovered from the growth medium, crude emulsan contained a complex consisting of about $10-20 \%$ protein, which also contributed to its amphipathicity and to the hydrocarbon substrate specificity $[48,52]$. Emulsan initially accumulated on the cell surface of RAG-1 cell as a minicapsule $[12,13,53]$ and subsequently gets released into the medium as an active emulsifier when the cells approach the stationary phase [12]. The release of the bioemulsifier depends on the presence of a suitable carbon and nitrogen source in the medium [11]. These requirements were presumable due to the de novo synthesis of amino sugar precursors and subsequent polymer synthesis which accompanies release of emulsan minicapsule. It was shown that some of the properties of an exocellular esterase activity from RAG-1 interact with emulsan and that emulsan was acting as a substrate for the release of the esterase enzyme from the cell surface [48].

It was repeatedly emphasized that the process of emulsan release 
Citation: Sekhon KK, Khanna S, Cameotra SS (2012) Biosurfactant Production and Potential Correlation with Esterase Activity. J Pet Environ Biotechnol 3:133. doi:10.4172/2157-7463.1000133

Page 6 of 10

\begin{tabular}{|c|c|c|c|c|c|c|c|c|c|c|c|c|c|c|}
\hline & 1 & 10 & 20 & 30 & 40 & 50 & 60 & 70 & 80 & 90 & 100 & 110 & 120 & \\
\hline \multirow{7}{*}{$\begin{array}{r}\text { Bacillus } \\
\text { B.clausii } \\
\text { srff,I7 } \\
\text { srfA,SPG } \\
\text { sfP,I7 } \\
\text { sfp,SP6 } \\
\text { sfp0,I7 } \\
\text { sfp0,SPG } \\
\text { Consensus }\end{array}$} & \multicolumn{14}{|c|}{ 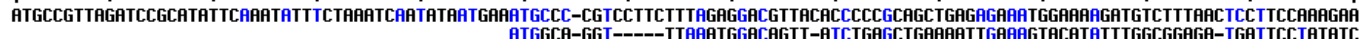 } \\
\hline & \multicolumn{14}{|c|}{ 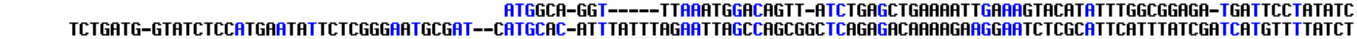 } \\
\hline & \multicolumn{14}{|c|}{ 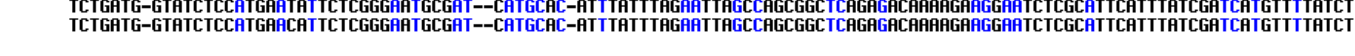 } \\
\hline & \multirow{2}{*}{\multicolumn{14}{|c|}{ 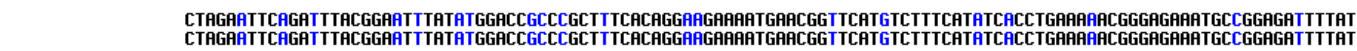 }} \\
\hline & & & & & & & & & & & & & & \\
\hline & \multicolumn{14}{|c|}{ 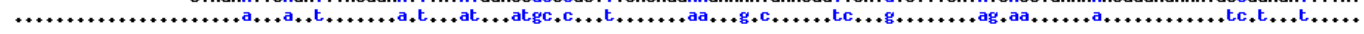 } \\
\hline & & 140 & 150 & 160 & 170 & 180 & 190 & 200 & 210 & 220 & 230 & 240 & 250 & 26 \\
\hline \multirow{8}{*}{$\begin{array}{r}\text { Bacillus } \\
\text { B.clausii } \\
\text { srff,I7 } \\
\text { srfA,SPG } \\
\text { sfP,I7 } \\
\text { sfp,SP6 } \\
\text { sfp0,I7 } \\
\text { sfp0,SP6 } \\
\text { Consensus }\end{array}$} & \\
\hline & \multirow{6}{*}{\multicolumn{14}{|c|}{ 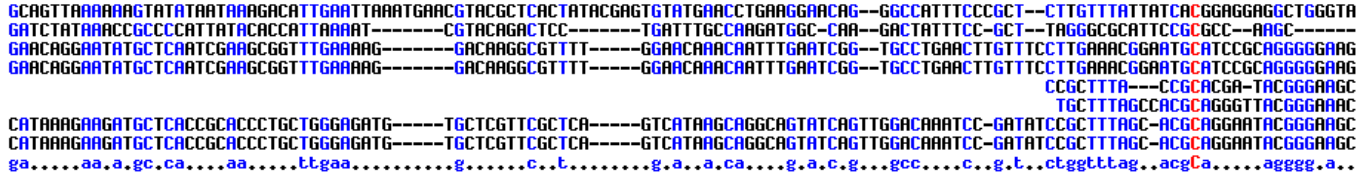 }} \\
\hline & & & & & & & & & & & & & & \\
\hline & & & & & & & & & & & & & & \\
\hline & & & & & & & & & & & & & & \\
\hline & & & & & & & & & & & & & & \\
\hline & & & & & & & & & & & & & & \\
\hline & 261 & 270 & 280 & 290 & 300 & 310 & 320 & 330 & 340 & 350 & 360 & 370 & 380 & \\
\hline
\end{tabular}

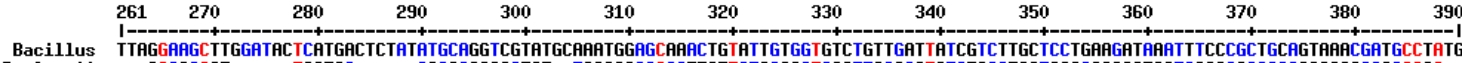

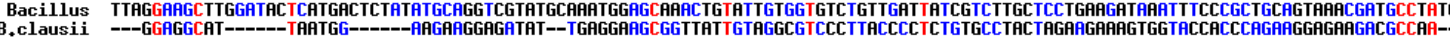

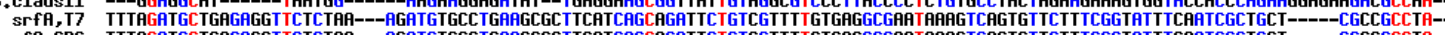

TITAGATGCTGAGAGGTTCTCTAA---AGATGTGCCTGAAGCGCTTCATCAGCAGHC

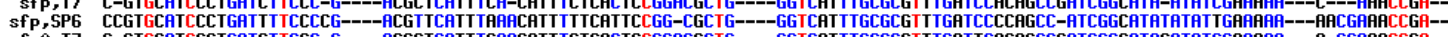

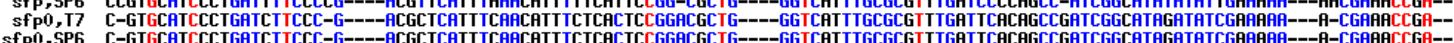

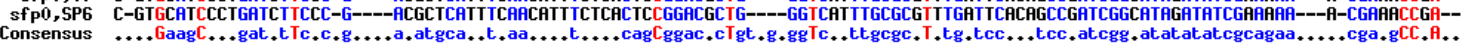

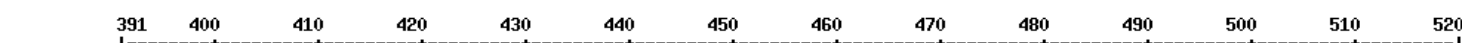

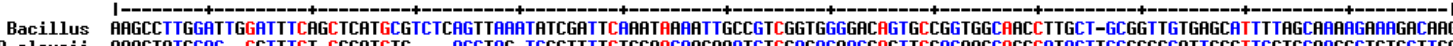

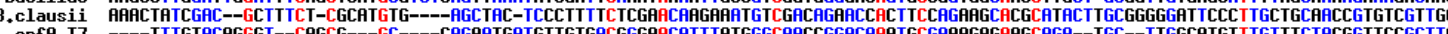

srff, , I7 ---NTGGCAGG

sfP,T7 ---TCAGCCTTG

sfp,sP6 -----TCAGCCT-GeGs

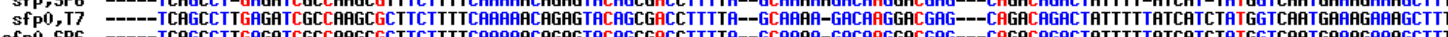

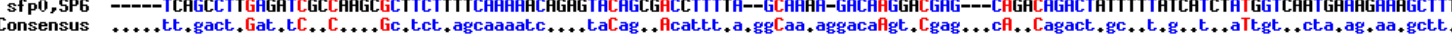

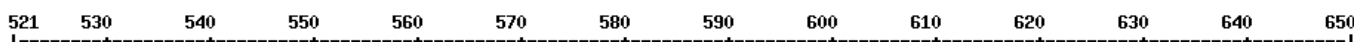

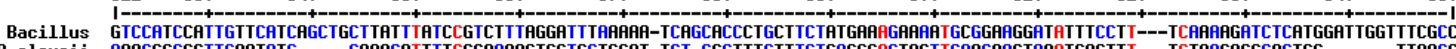

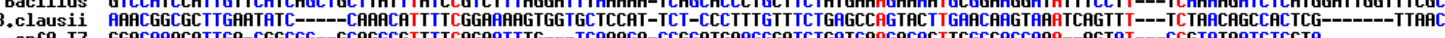

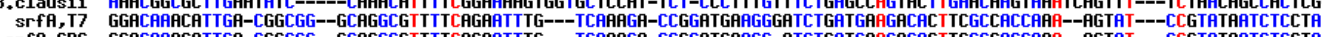

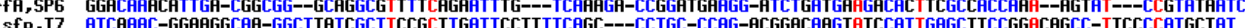

sf

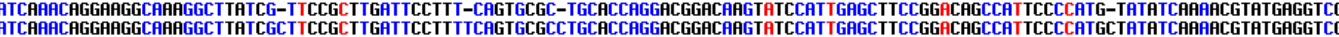
ATCAARCAGGARGGCAAFGGCTTATCGCTTCCGCTTGATTCCTITTCAGTGCGCCTGCACCAGGACGGACAAGTATCCATTGAGCTTCCGGACAGCCATTCCCCATGCTATATCAAAACGTATGAGGTC

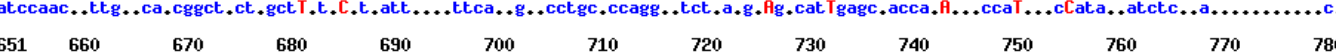

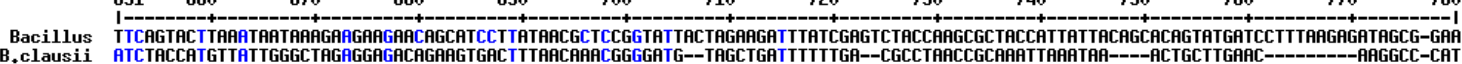
B.clausii ATCTACCATGTTHTGGGCTGAGGAGCAGAAG
srfa, 7

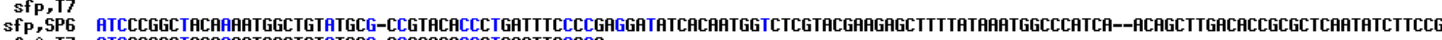
sf 0, I7
ATCCCGGCTACAARATGGCTGTATGCG-CCGCACACCCTGAATTCCCCA

sfP0,SP6 ATCCGGCTACAARATGGCTGTATGCG-CCGCACACCCTGAATTCCCCA

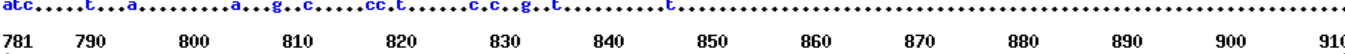

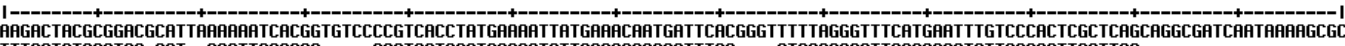

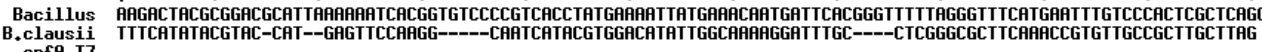

srfA,I7

sf $\mathrm{P}, \mathrm{T}$ ?

sfP,
sfpo, sf 0 , T

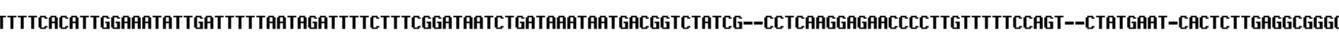
Consensus

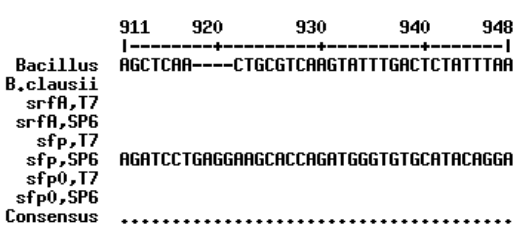

Figure 1: MultAlin (Multiple Sequence Alignment) of $s f p$, sfp 0 and srfA gene sequences with esterase gene sequences from NCBI database. The consensus sequences are shown in the last line of the alignment table. Bacillus=Bacillus sp. NK13 esterase gene (Liu et al. 2005, PubMed Accession number: DQ196347). B. clausii=Bacillus clausii KSM-K16 esterase gene (Hakamada et al. 1994, PubMed Accession number: AP006627). sfp, sfp0 and srfA are gene sequences responsible for biosurfactant production in Bacillus subtilis SK320. (Sekhon et al, 2011)

requires the presence of an active esterase on the cell surface of A. calcoaceticus RAG-1 in presence of chloramphenicol [48]. In the absence of a carbon source, the esterase was released, whereas emulsan was retained on the cell surface. Once esterase was removed the emulsan was no longer released in the complete chloramphenicol system supplemented with a carbon source. Therefore, the release of esterase required the presence of nitrogen, but not necessarily a carbon source. Subsequently, the esterase enzyme was partially purified from the cell bound emulsan of A. calcoaceticus RAG-1. The partially purified enzyme catalyzed the hydrolysis of acetyl and other acyl groups from triglycerides and alkyl esters. Gel-filtration confirmed that the cell-free enzyme released from the cell surface was either emulsan free or associated with the bioemulsifier. The partially purified enzyme was found to interact specifically with the esterified fully active 


\begin{tabular}{|c|c|c|c|c|}
\hline $\begin{array}{l}\text { Substrate/Carbon source } \\
\text { used }\end{array}$ & Biosurfactant type & Producer strain & Finding & References \\
\hline Absolute ethanol & $\begin{array}{l}\text { Heteropolysaccharide } \\
\text { bioemulsifier }\end{array}$ & $\begin{array}{l}\text { Acinetobacter calcoaceticus } \\
\text { RAG-1 }\end{array}$ & Emulsan acts as substrate for esterase enzyme & [Shabtai and Gutnick, 1985] \\
\hline $\begin{array}{l}\text { Ethanol or Sodium acetate or } \\
\text { Hexadecane or Crude oil }\end{array}$ & $\begin{array}{l}\text { Heteropolysaccharide } \\
\text { bioemulsifier }\end{array}$ & $\begin{array}{l}\text { Acinetobacter calcoaceticus } \\
\text { RAG-1 }\end{array}$ & $\begin{array}{l}\text { Emulsan producing RAG-1 capable of growing } \\
\text { whereas emulsan deficient mutant failed to grow } \\
\text { on crude oil }\end{array}$ & [Pines and Gutnick, 1986] \\
\hline Glucose & Mannoprotein emulsifier & Saccharomyces cerevisiae & Mannoprotein acting as effective bioemulsifier & [Cameron et al, 1988] \\
\hline Glucose or ethanol & $\begin{array}{l}\text { Heteropolysaccharide } \\
\text { bioemulsifier }\end{array}$ & $\begin{array}{l}\text { Acinetobacter calcoaceticus } \\
\text { RAG-1 }\end{array}$ & $\begin{array}{l}\text { Esterase coding gene from RAG-1 cloned- } \\
\text { expressed in E.coli. E.coli able to grow on } \\
\text { triglycerides such as TAC. }\end{array}$ & [Reddy et al, 1989] \\
\hline Sodium acetate & Polysaccharide & $\begin{array}{l}\text { Acinetobacter radioresistens } \\
\text { KA53 }\end{array}$ & $\begin{array}{l}\text { Protein moiety essential for structure and emulsi- } \\
\text { fying activity of bioemulsifier, alasan }\end{array}$ & [Navon-Venezia et al, 1995] \\
\hline Absolute ethanol & $\begin{array}{l}\text { Heteropolysaccharide } \\
\text { bioemulsifier }\end{array}$ & $\begin{array}{l}\text { Acietobacter venetianus } \\
\text { RAG-1 }\end{array}$ & $\begin{array}{l}\text { Exocellular protein esterase enhances emulsify- } \\
\text { ing activity of emulsan. Deproteinized product, } \\
\text { apoemulsan, failed to form/stabilize oil-water } \\
\text { emulsions. }\end{array}$ & [Bach et al, 2003] \\
\hline Ethanol & $\begin{array}{l}\text { Heteropolysaccharide } \\
\text { bioemulsifier }\end{array}$ & $\begin{array}{l}\text { Acietobacter venetianus } \\
\text { RAG-1 }\end{array}$ & $\begin{array}{l}\text { his-tagged recombinant from RAG-1 formed } \\
\text { hexadecane-in-water emulsions with } 18 \text { different } \\
\text { polysaccharides }\end{array}$ & [Bach and Gutnick, 2006] \\
\hline Olive oil & Lipopeptide & Bacillus sp. SK320 & $\begin{array}{l}\text { Esterase and biosurfactant activity exhibiting } \\
\text { Bacillus sp. and its recombinant, capable of } \\
\text { emulsifying olive oil completely }\end{array}$ & [Khanna et al, 2009] \\
\hline Olive oil & Lipopeptide & Bacillus sp. SK320 & $\begin{array}{l}\text { Enhanced biosurfactant production through } \\
\text { cloning of three genes and role of esterase in } \\
\text { biosurfactant release }\end{array}$ & [Sekhon et al, 2011] \\
\hline
\end{tabular}

Table 5: Studies undertaken on biosurfactant-esterase complex.

emulsan, but not with the de-esterified polymer. A role for esterase in emulsan release from the cell surface was indicated when the enzyme was preferentially depleted from the cell surface under conditions in which emulsan was not released. Such cells lost the capacity to release the biopolymer.

The cell surface esterase (molecular mass $34.5 \mathrm{kDa}$ ) associated with the emulsan was later characterized, cloned and over-expressed in Escherichia coli BL21 (DE3) behind the phage T7 promoter with the Histag system and after over- expression, recovery of about 80 to $90 \%$ of the protein in the inclusion bodies was reported [14]. The over- expressed esterase was recovered from the inclusion bodies by solubilization with deoxycholate and, after slow dialysis, was purified by metal chelation affinity chromatography. Mixtures containing apoemulsan and the recombinant esterase isolated from cell extracts formed stable oilwater emulsions with very hydrophobic substrates such as hexadecane under conditions in which emulsan itself was ineffective. Similarly, a series of esterase-defective mutants were generated by site-directed mutagenesis, cloned, and over-expressed in E. coli. Mutant proteins defective in catalytic activity as well as others apparently affected in protein conformation were also active in enhancing the apoemulsanmediated emulsifying activity. Other proteins, including a His-tagged over-expressed esterase from the related organism A. calcoaceticus BD4, showed no enhancement. Various other microbial proteins have been reported to play a constructive role in emulsification. The his-tagged recombinant esterase from Acenitobacter venetianus RAG-1 has been shown to confer emulsifying activity on 18 different polysaccharides from microbial, plant, insect and synthetic sources and formed stable hexadecane-in-water emulsions. Emulsions in presence of 7 polysaccharides exhibited $80 \%$ stability [54].

In another study conducted in 1986 [55] researchers have shown that emulsan-deficient mutants of $A$. calcoaceticus RAG-1 grew very poorly on crude oil when compared with the parent strain, regardless of whether emulsan was supplemented in the medium or not. Results emphasized that the capability of producing emulsan facilitated the cells to grow on crude oil. Furthermore, a putative esterase gene (est) from
A. calcoaceticus RAG-1 was cloned into Escherichia coli [47]. Esterasepositive clones exhibited high levels of esterase activity even in intact cells. In addition, expression of the est gene conferred on E.coli the ability to grow on simple triglycerides such as triacetin (TAC), utilizing it as a source of carbon and energy. Mutants of RAG-1 defective in esterase were found to be defective in emulsan production and release. These two studies were in accordance with the formation of emulsion in the presence of olive oil by the recombinant cells of Bacillus subtilis SK320 emphasizing that the cloning of the biosurfactant gene conferred on the E.coli cells the ability to utilize olive oil as a sole carbon source $[3,44,45]$. The genes sfp (1210 bp), sfp0 (642 bp) and srfA (707 bp) (DDBJ/EMBL/GeneBank accession numbers: EU822921, EU822922, EU822923) of the recombinants strains BioS a, BioS b and BioS c were cloned and used to infer functional and evolutionary relationship between sequences in the database. The amino acid sequences from $s f p, s f p 0$ and $s r f A$ biosurfactant genes were aligned with two of the esterase gene sequences: Bacillus sp. NK13 esterase gene, complete cds [56] (PubMed Accession number: DQ196347) and Bacillus clausii KSM-K16 DNA, complete genome, esterase gene [57] (PubMed Accession number: AP006627). The results revealed similarity as well as conserved family characteristics between biosurfactant genes and esterase genes taken from the database for multiple alignments, concluding that the biosurfactant production genes had some role to play for the release of esterase protein in the culture medium (Figure 1) [3].

The role of a protein (or an enzyme) in the emulsifying activity of biosurfactants is difficult to rule out. This was recognized when the mannoprotein of Saccharomyces cerevisia (a major component of the cell wall and an effective bioemulsifier) after treatment with a proteolytic enzyme pronase lost its ability to stabilize emulsions [58], just as treatment with proteinases or phenol, the protein component of alasan, a bioemulsan, isolated from Acinetobacter radioresistens KA53 is left with no emulsifying activity $[59,60]$. Alasan activity was shown to be sensitive to pronase and $95 \%$ emulsifying activity was lost when protein component (apoalasan) was removed with hot phenol treatment. In case of A. calcoaceticus $\mathrm{BD} 4$, both fractions of the protein- 


\begin{tabular}{|l|l|l|}
\hline Hydrophobic substrate & Average emulsifying activity (SD) \\
\hline & Emulsan (U/mg) & $\begin{array}{l}\text { Apoemulsan+esterase } \\
\text { (U/mg of apoemulsan/ } \\
\text { mg of esterase) }\end{array}$ \\
\hline Anthracene & 0 & $970(170)$ \\
\hline Crude oil & $1,100(140)$ & $4,900(800)$ \\
\hline Dicyclohexane & $310(50)$ & $2,800(500)$ \\
\hline Diesel oil & $730(130)$ & $4,200(700)$ \\
\hline Eicosane & 0 & $1,800(260)$ \\
\hline Fluoranthene & 0 & $590(150)$ \\
\hline Heptadecane & $120(25)$ & $2,400(380)$ \\
\hline Immersion oil & $75(15)$ & $780(100)$ \\
\hline 2-Methylnapthalene & 0 & $2,000(400)$ \\
\hline Mineral oil & $450(80)$ & $3,000(400)$ \\
\hline Octadecane & 0 & $2,200(320)$ \\
\hline Petroleum refinery sludge & $580(95)$ & $1,200(220)$ \\
\hline Pyrene & 0 & $420(75)$ \\
\hline Soya oil & 0 & $1,300(190)$ \\
\hline Squalene & 0 & $600(150)$ \\
\hline n-Tetracosane & 0 & $510(75)$ \\
\hline
\end{tabular}

[Gutnick et al, 2003]

Table 6: Enhancement of apoemulsan activity on different hydrophobic substrates by recombinant esterase.

polysaccharide complex are absolutely required for emulsification [61], while in Acinetobacter radioresistens KA53 the protein itself is the active emulsifying agent [62]. Boiling or incubating the lipopeptides purified from Bacillus subtilis SK320 and its recombinants BioS a, $\mathrm{BioS} \mathrm{b}$ and BioS $\mathrm{c}$ with proteinase $\mathrm{K}$ led to a decrease in emulsifying activity of the lipopeptide biosurfactant [3]. Further it was shown that the protein in emulsan is not an active bioemulsifier by itself but rather enhances the activity of the polysaccharide component, apoemulsan. The portion of the esterase protein that is responsible for emulsification enhancement still needs to be identified [14] and possibly a challenging field of research.

The genes responsible for the biosynthesis and control of emulsan heteropolysaccharide emulsan were also targeted [63]. The genes were cloned, sequenced and shown to exist within a single $27 \mathrm{kbp}$ gene cluster termed as wee regulon in the A. venetianus, but little is known about the protein components of the emulsan complex. Emulsan released from bacterial cell surface is apparently mediated by one of the key proteins i.e by the action of cell surface esterase which is encoded by the est gene (909 bp). This est gene has been cloned, sequenced and over-expressed in E. coli [64]. Mutants deleted for several of these genes were defective in emulsification, indicating that the polysaccharide is absolutely essential for extracellular emulsifying activity. In support of this finding the apoemulsan recombinant-esterase mixture was investigated for emulsification of a wide range of pure and crude oil products from a variety of sources and the activities were compared with that of fully proteinated emulsan (Table 6) [14], and results revealed that the esterase-apoemulsan complex was actually more effective in emulsifying a variety of hydrophobic substrates that are normally not emulsified by crude emulsan itself [14].

There is increasing interest for isolating new enzymes and new enzyme producing strains for their use in industrial conversions [65]. Enzymes like lipases, esterases, cellulases, xylanases and pectinases play a significant role in many industrial operations. Bacteria produce and secrete esterases which typically show the highest activity towards the soluble state of its substrate [66]. According to recent findings, esterases play a role in degradation of natural materials and industrial pollutants like cereal wastes, plastics and some other toxic chemicals

[7]. Some esterases may be involved in plant pathogenicity, carbon source provision and biocide detoxification [67], others catalyze inter-esterification, aminolysis, and peracid formation [68]. Not only this; lipases and esterases have also been used successfully in organic synthesis of optically pure substances, perfumes and antioxidants [7,69-76].

The studies till date on the biosurfactant-esterase complex focused on the emulsifying capability of the complex which has been utilized for bioremediation purpose due to its extraordinary surface-active property. Future research must be focused on better understanding of the interaction between the biosurfactant-esterase complex and the hydrocarbon, and the degradation pathway of the hydrocarbon.

\section{Future Prospects and Concluding Remarks}

Due to their environmentally friendly nature and increased awareness among the masses for natural products, biosurfactants have carved a niche for themselves in the market today. Manufacturers are staking money on biosurfactants because of their promising properties. Using mutants or super active microbial strains with high yielding capacities and cheap renewable substrates as raw material the production of biosurfactants has been ameliorated at industrial level. Current market trends show that the demand of biosurfactants such as rhamnolipids, glycolipids, lipopeptides, phospholipids and sophorolipids is going to increase manifolds because of their utility in detergent, paint, cosmetics, textile, agriculture, food and pharmaceutical industries. Biosurfactants are put to maximum usage for their environmental applications such as bioremediation and dispersion of oil spills. The addition of microbial surfactants enhances the solubility and removal of some major soil contaminants. Biosurfactant (bioemulsifier) production with esterase activity in the culture media shows two-fold increase in the emulsification of hydrophobic substrates ascertaining that the biosurfactant-esterase complex could also be instrumental in the remediation of polluted sites.

\section{Acknowledgements}

The first/corresponding author is thankful to CORE and DBTES, Thapa University, Patiala where this $\mathrm{PhD}$ research work was conducted. The first corresponding author dedicates this article to Dr Sunil Khanna (NIIT University, Rajasthan), Dr Swaranjit Singh Cameotra (IMTECH, Chandigarh) and Dr N Tejo Prakash (Thapar University, Patiala) for their support.

\section{References}

1. Banat IM (1995) Biosurfactants production and possible uses in microbia enhanced oil recovery and oil pollution remediation: a review. Biores Techno 51:1-12.

2. Rahman KSM, Rahman TJ, McClean S, Marchant R, Banat IM (2002) Rhamnolipid biosurfactant production by strains of Pseudomonas aeruginosa using low-cost raw materials. Biotechnol Prog 18:1277-1281.

3. Sekhon KK, Khanna S, Cameotra SS (2011) Enhanced biosurfactant production through cloning of three genes and role of esterase in biosurfactant release. Micro Cell fact 10: 49 .

4. Benjamin S, Pandey A (1998) Candida rugosa lipases: Molecular biology and versatility in biotechnology. Yeast 14: 1069-1087.

5. Carlsen S (1994) Lipolytic enzymes and their use in the oleo chemical and detergent industry. Fat Sci Technol 96: 408.

6. Tsujita T, Shirai K, Saito Y, Okuda H (1990) Relationship between lipase and esterase. Prog Clin Biol Res 344: 915-933.

7. Panda T, Gowrishankar BS (2005) Production and applications of esterases Appl Microbiol Biotechnol 67: 160-69.

8. Rubina S, Khanna S (1995) Biosurfactants. Ind J Microbiol 35: 165-184

9. Christofi N, Ivshina I (2002) Microbial surfactants and their use in soil 
remediation. Book: Bioremediation of aquatic and terrestrial ecosystems 311 327

10. Maier RM, Bodour AA, Drees KP (2003) Distribution of biosurfactant producing bacteria in undisturbed and contaminated arid southwestern soils. Appl Environ Microbiol 69: 3280-3287.

11. Rubinovitz C, Gutnick DI, Rosenberg E (1982) Emulsan production by Acinetobacter calcoaceticus in the presence of chloramphenicol. J Bacterio 152: $126-132$.

12. Goldmann S, Shabtai Y, Rubinovitz C, Rosenberg E, Gutnick DL (1982) Emulsan production in Acinetobacter calcoaceticus: distribution of cell free and cell associated cross-reacting material. Appl Environ Microbiol 44: 165-170.

13. Pines O, Bayer EA, Gutnick DL (1983) Localization of emulsan-like polymers associated with cell surface of Acinetobacter calcoaceticus. J Bacteriol 154 893-905.

14. Gutnick D, Bach H, Berdichevsky Y (2003) An exocellular protein from the oildegrading microbe Acinetobacter venetianus RAG-1 enhances the emulsifying activity of the polymeric bioemulsifier emulsan. Appl Environ Microbiol 69: 2608-2615.

15. Cooper DG, Goldenberg BG (1987) Surface-active agents from two Bacillus species. Appl Environ Microbiol 53: 224-229.

16. Peypoux F, Bonmatin JM, Wallach J (1999) Recent trends in the biochemistry of surfactin. App Microbiol Biotechnol 51: 553-563.

17. Hisatsuka K, Nakahara T, Sano N, Yamada K (1971) Formation of rhamnolipid by P.aeruginosa and its function in hydrocarbon fermentation. Agric Biol Chem 35: 686-692.

18. Kaplan N, Rosenberg E (1982) Exopolysaccharide distribution and bioemulsifier production in Acinetobacter calcoaceticus BD-4 and BD413. Appl Environ Microbiol 44: 1335-1341.

19. Persson A, Osterberg E, Dostalek M (1988) Biosurfactant production by Pseudomonas fluorescens 3growth and product characteristics. Appl Microbio Biotechnol 29: 1-4.

20. Shoda M, Ohno A, Ano T (1992) Production of a lipopeptide antibiotic surfactin with recombinant Bacillus subtilis. Biotech Lett 14: 1165-1168.

21. Michel G, Sandrin C, Peypoux F (1990) Coproduction of surfactin and Iturin A, lipopeptides with surfactant and antifungal properties, by Bacillus subtilis. Biotechnol App Biochem 12: 370-375.

22. Muthusamy K, Gopalakrishnan S, Ravi TK, Sivachidambaram P (2008) Biosurfactants: Properties, commercial production and application. Cur Science 94: 736-747.

23. Cooper DG, MacDonald CR, Duff SJ, Kosaric N (1981) Enhanced production of surfactin from Bacillus subtilis by continuous product removal and metal cation additions. Appl Environ Microbiol 42: 408-412.

24. Quadri LE, Weinred PH, Lei M, Nakano MM, Zuber P, et al. (1998) Characterization of sfp, a Bacillus subtilis phosphopantetheinyl transferase for peptidyl carrier protein domains in peptide synthetases. Biochem. 37: 1585-95.

25. Javaheri M, Jenneman GE, Mclnerney MJ, Knapp RM (1985) Anaerobic production of a biosurfactant by Bacillus licheniformis JF-2. App Environ Microbiol 50: 698-700.

26. Yakimov MM, Timmis KN, Wray V, Fredrickson HL (1995) Characterization of a new lipopeptide surfactant produced by thermotolerant and halotolerant subsurface Bacillus licheniformis BAS50. Appl Environ Microbiol 61: 17061713.

27. Mulligan CN (2005) Environmental applications for biosurfactants. Environ Pol 133: 183-198.

28. Anna LMS, Sebastain GV, Menezes EP, Alves TLM, Santos AS, et al. (2002) Production of biosurfactants from Pseudomonas aeruginosa PA1 isolated in oil environments. Brazilian J Chem Engg 19: 159-166.

29. Tsuge K, Ano T, Shoda M (1996) Isolation of a gene essential for biosynthesis of the lipopeptide antibiotics plipastatin B1 and surfactin in Bacillus subtilis YB8. Arch Microbiol 165: 243-251.

30. Tsuge K, Ano T, Hirai M, Nakamura Y, Shoda M (1997) The genes degQ, pps and Ipa-8 (sfp) are responsible for conversion of Bacillus subtilis 168 to plipastatin production. Antimicrob Agents Chemother. 43: 2183-92.
31. Mulligan CN, Sheppard JD (1987) The production of surfactin by Bacillus subtilis grown on peat hydrolysate. App Microbiol Biotechnol 27: 110-116.

32. Rahman KS, Rahman TJ, McClean S, Marchant R, Banat IM (2002) Rhamnolipid biosurfactant production by strains of Pseudomonas aeruginosa using low-cost raw materials. Biotechnol Prog 18: 1277-1281.

33. Parveen J, Wan MFWN, Md Z A (2012) Optimum medium components for biosurfactant production by Klebsiella pneumoniae WMF02 utilizing sludge palm oil as substrate. Aust J Basic Appl Sci 6: 100-108.

34. Khopade A, Biao R, Liu X, Mahadik K, Zhang L, et al. (2012) Production and stability studies of biosurfactant isolated from marine Nocardiopsis sp. B4. Desalination 285: 198-204

35. Roongsawang N, Thaniyavarn J, Thaniyavarn S, Kameyama T, Haruki M, et al. (2002) Isolation and characterization of a halotolerant Bacillus subtilis BBK1 which produces three kinds of lipopeptides: bacillomycin L, plipastatin, and surfactin. Extremophiles 6: 499-506

36. Aparna A, Srinikethan G, Hegde S (2012) Isolation, screening and production of biosurfactant by Bacillus clausii 5B. Res in Biotechnol 3: 49-56.

37. Dubey KV, Charde PN, Meshram SU, Yadav SK, Singh S, et al. (2012) Potentia of new microbial isolates for biosurfactant production using combinations of distillery waste with other industrial wastes. J Petrol Environ Biotechnol.

38. Thavasi RS, Jayalakshmi, Banat IM (2011) Application of biosurfactant produced from peanut oil cake by Lactobacillus delbrueckii in biodegradation of crude oil. Bioresource Technology. Bioresour Technol 102: 3366-3372.

39. Thavasi RS, Jayalakshmi, Balasubramaian T, Banat IM (2011) Biosurfactant production by Pseudomonas aeruginosa from renewable resources. Indian J Microbiol 51: 30-36.

40. Thavasi RS, Jayalakshmi, Balasubramaian T, Banat IM (2007) Biosurfactan production by Corynebacterium kutscheri from waste motor lubricant oil and pea nut oil cake. Lett Appl Microbiol 45: 686-691.

41. Ines M, Semia C-E, Dhouha G (2012a) Optimization of the nutritional parameters for enhanced production of $B$. subtilis SPB1 biosurfactant in submerged culture using response surface methodology. Biotechnol Res Intl.

42. Ines M, Semia E-C, Dhouha G (2012b) Optimization of Inocula Conditions fo Enhanced Biosurfactant Production by Bacillus subtilis SPB1, in Submerged Culture, Using Box-Behnken Design.

43. Saikia RR, Deka S, Deka M, Sarma H (2012) Optimization of environmental factors for improved production of rhamnolipid biosurfactant by Pseudomonas aeruginosa RS29 on glycerol. J Basic Microbiol 52: 446-457.

44. Khanna S, Sekhon KK, Prakash NT (2009) Cloning and expression of biosurfactant gene from endosulfan degrading Bacillus sp: correlation between esterase activity and biosurfactant production. Biotechnology 8: 235-241.

45. Sekhon KK, Prakash NT, Khanna S (2009) Cloning, expression and genetic regulation of a biosurfactant gene for bioremediation of hydrophobic chemical compounds. J Pure Appl Microbiol 3: 49-58.

46. Benjamin S, Pandey A (1998) Candida rugosa lipases: Molecular Biology and versatility in Biotechnology. Yeast 14: 1069-1087.

47. Reddy PG, Allon R, Mevarech M, Mendelovitz S, Sato Y, et al. (1989) Cloning and expression in Escherichia coli of an esterase coding gene from the oildegrading bacterium Acinetobacter calcoaceticus RAG-1. Gene 76:145-152.

48. Shabtai Y, Gutnick DL (1985) Exocellular esterase and emulsan release from the cell surface of Acinetobacter calcoaceticus. J Bacteriol 161: 1176-1181.

49. Zosim Z, Fleminger G, Gutnick DL, Rosenberg E (1989) Effect of protein on the emulsifying activity of emulsan. J Disp Sci Technol 10: 307-317.

50. Zuckerberg A, Diver A, Peeri Z, Gutnick DL, Rosenberg E (1979) Emulsifier of Arthrobacter RAG-1: Chemical and Physical properties. Appl Environ Microbio 37: $414-420$

51. Belsky I, Gutnick DL, Rosenberg E (1979) Emulsifier of Arthrobacter RAG1: determination of emulsifier bound fatty acids. FEMS Lett 101: 175-178.

52. Zosim Z, Gutnick D, Rosenberg E (1982) Properties of hydrocarbon-in-wate emulsions stabilized by Acinetobacter RAG-1 emulsion. Biotechnol. Bioeng 24 281-292.

53. Pines O, Gutnick DL (1984) Specific binding of a bacteriophage at a hydrocarbon-water interface. J Bacteriol 157: 179-183. 
Citation: Sekhon KK, Khanna S, Cameotra SS (2012) Biosurfactant Production and Potential Correlation with Esterase Activity. J Pet Environ Biotechnol 3:133. doi:10.4172/2157-7463.1000133

Page 10 of 10

54. Bach H, Gutnick DL (2006) Novel polysaccharide-protein based amphipathic formulations. Appl Microbiol Biotechnol 71: 34-38.

55. Pines O, Gutnick D (1986) Role for emulsan in growth of Acinetobacter calcoaceticus RAG-1 on crude oil. Appl Environ Microbiol 51: 661-663.

56. Liu G, Tan Z, Zhang J (2005) Cloning of esterase gene from Bacillus sp. NK13. Submitted to EMBL/GenBank/DDBJ databases.

57. Hakamada Y, Kobayashi T, Hitomi J, Kawai S, Ito S (1994) Molecular cloning and nucleotide sequence of the gene for an alkaline protease from the alkalophilic Bacillus sp. KSM-K16. J Ferment Bioeng 78: 105-108.

58. Cameron DR, Cooper DG, Neufeld RJ (1988) The mannoprotein of Saccharomyces cerevisiae is an effective bioemulsifier. Appl Environ Microbiol 54: $1420-1425$

59. Navon-Venezia S, Zosim Z, Gottlieb A, Legmann R, Carmeli S, et al. (1995) Alasan: a new bioemuslier from Acinetobacter radioresistens. Appl Environ Microbiol 61: 3240-3244.

60. Navon-Venezia S, Banin E, Ron EZ, Rosenberg E (1998) The bioemulsifie alasan: role of protein in maintaining structure and activity. Appl Microbio Biotechnol 49: 382-384.

61. Kaplan N, Zosim Z, Rosenberg E (1987) Reconstitution of emulsifying activity of Acinetobacter calcoaceticus BD4 emulsan by pure polysaccharide and protein. Appl Environ Microbiol 53: 440-446.

62. Toren A, Navon-venezia S, Ron EZ, Rosenberg E (2001) Emulsifying activities of purified alasan proteins from Acinetobacter radioresistens KA53. Appl Environ Microbiol 67: 1102-1106.

63. Nakar D, Gutnick DL (2001) Analysis of the wee gene cluster responsible for the biosynthesis of the polymeric bioemulsifier from the oil-degrading strain Acinetobacter /woffii RAG-1. Microbiol 147: 1937-1946.

64. Alon RN, Gutnick DL (1993) Esterase from the oil-degrading Acinetobacter Iwoffii RAG-1: sequence analysis and over-expression in Escherichia coli. FEMS Microbiol Lett 112: 275-280.

65. Cherry JR, Fidantsef AL (2003) Directed evolution of industrial enzymes: an update. Curr Opin Biotechnol 14: 438-443.
66. Fojan P, Jonson PH, Petersen MT, Petersen SB (2000) What distinguishes an esterase from a lipase: a novel structural approach. Biochimie 82: 1033-1041.

67. Khalameyzer V, Fischer I, Bornscheuer UT, Altenbuchner J (1999) Screening nucleotide sequence, and biochemical characterization of an esterase from Pseudomonas fluorescens with high activity towards lactones. Appl Environ Microbiol 65: 477-482.

68. Bornscheuer UT (2002) Microbial carboxyl esterases: Classification, properties and application in biocatalysis. FEMS Microbial Rev 733: 1-9.

69. Ollis DL, Cheah E, Dijkstra B, Frolow F, Franken S, et al. (1992) The $\alpha / \beta$ hydrolase fold. Protein Eng 5: 197-211.

70. Nishizawa M, Gomi H, Kishimoto F (1993) Purification and some properties of carboxylesterase from Arthrobacter globiformis; stereoselective hydrolysis of ethyl chrysanthemate. Biosci Biotechnol Biochem 57: 594-598.

71. Nishizawa M, Shimizu M, Ohkawa H, Kanaoka M (1995) Stereo selective production of (+)-trans-chrysanthemic acid by a microbial esterase: cloning, nucleotide sequence, and over expression of the esterase gene of Arthrobacter globiformis in Escherichia coli. App Environ Microbiol 61: 3208-3215.

72. Quax WJ, Broekhuizen CP (1994) Development of a new Bacillus carboxy esterase for use in the resolution of chiral drugs. Appl Microbiol Biotechnol 41 : 425-431.

73. Moore JC, Arnold FH (1996) Directed evolution of a para-nitrobenzyl esterase for aqueous-organic solvents. Nat Biotechnol 14: 458-467.

74. Rathbone DA, Holt PJ, Lowe CR, Bruce NC (1997) Molecular analysis of the Rhodococcus sp. strain $\mathrm{H} 1$ her gene and characterization of its product, a heroin esterase expressed in Escherichia coli. App Environ Microbiol 63: 2062 2066

75. Enzelberger MM, Bornscheuer UT, Gatfield I, Schmid RD (1997) Lipasecatalyzed resolution of $\gamma$ - and $\delta$-lactones. J. Biotechnol. 56: 1.

76. Kazlauskas RJ, Bornscheuer UT (1998) Biotransformations with lipases. 37191. In H. J. Rehm, A. Puhler, P. J. W. Stadler and D. R. Kelly (edi) Biotechnology series, Vol 8a Wiley-VCH, Weinheim, Germany. 